\title{
Influence of Sex-linked Genes on Embryonic Sensitivity to Cortisone in Three Strains of Mice ${ }^{1}$
}

\author{
B. M. FRANCIS ${ }^{2}$ \\ Area Program in Genetics, University of Michigan, \\ Ann Arbor, Michigan 48104
}

\begin{abstract}
It was postulated that sex-linked genes affecting embryonic sensitivity to cortisone-induced cleft palate and cortisone-induced resorption might differ between inbred mouse strains showing pronounced reciprocal effects. The three strains tested were the A/J (A), C57BL/6J (B), and $\mathrm{C} 3 \mathrm{H} / \mathrm{HeJ}(\mathrm{C})$, whose sensitivities to cortisone-induced cleft palate had been shown to be: $A>C>B$. The sensitivity of reciprocal $\mathrm{A} \times \mathrm{B}$ and $\mathrm{B} \times \mathrm{C}$ hybrid embryos was matroclinous; of reciprocal $A \times C$ embryos, patroclinous. Backcrosses of reciprocal $F_{1}$ hybrid males to inbred females were used to test the hypothesis of sex-linkage with respect to the incidence of cortisone-induced cleft palate, cortisone-induced resorption, and the overall level of cortisone-induced fetal damage. The results were consistent with the hypothesis that sex-linked genes affecting embryonic sensitivity to cortisone-induced cleft palate, but not to cortisone-induced resorption, differ in the three strains.
\end{abstract}

The incidence of cortisone-induced cleft palate (CP) is greater in $\mathrm{A} / \mathrm{J}$ than in C57BL/ 6 mice (Fraser and Fainstat, '51). The matroclinous sensitivity of offspring of reciprocal crosses between the $\mathrm{A} / \mathrm{J}$ and C57BL/ 6 strains was shown to be independent of cytoplasmic factors (Kalter, '54). In analogous crosses between $\mathrm{A} / \mathrm{J}$ and the relatively resistant $\mathrm{C} 3 \mathrm{H}$ strain, Kalter ('65) found patroclinous sensitivity in reciprocal $F_{1}$ embryos. Patroclinous sensitivity was also found in offspring of reciprocal crosses between the $\mathrm{A} / \mathrm{St}$ and $\mathrm{C} 3 \mathrm{H}$ strains (Loevy, '62, '63). Between the C3H and $\mathrm{C} 57 \mathrm{BL} / 6$ lines, however, matroclinous sensitivity obtains; $\mathrm{C} 3 \mathrm{H}$ was found to be more sensitive than C57BL/6 (Francis, '71).

On the basis of these studies a model was constructed for sex-linked inheritance of sensitivity to cortisone-induced $\mathrm{CP}$, which accounts for the observed pattern of matroclinous and patroclinous sensitivities in the offspring of reciprocal crosses between the $\mathrm{A} / \mathrm{J}, \mathrm{C} 57 \mathrm{BL} / 6$, and $\mathrm{C} 3 \mathrm{H} / \mathrm{HeJ}$ strains, hereafter referred to as strains $A, B$, and $C$, respectively. The model states that, whereas the relative sensitivities of the three lines to cortisone-induced $\mathrm{CP}$ are $\mathrm{A}>\mathrm{C}>\mathrm{B}$, the contributions of $\mathrm{X}$-linked genes to sensitivity are $X_{C}>X_{A}>X_{B}$. $\left(X_{C}\right.$ represents the hypothetical X-linked gene found in the $C$ strain, $X_{A}$ its allele in the A strain, and $X_{B}$ the corresponding allele in the $B$ strain.) Since sensitivity to cortisone-induced CP is affected by maternal factors as well as by several genes (Fraser et al., '54; Kalter, '54; Loevy, '63), reciprocal backcrosses were used to test the hypothesis of sex-linkage. Male offspring of reciprocal crosses between inbred lines differ in the origin of their sex chromosomes. If such $F_{1}$ males are backcrossed to the parent strains, female offspring of the reciprocal backcrosses will differ in one X-chromosome. The cytoplasmic inheritance and prenatal environments do not differ between such crosses. In the present study parallel matings of hybrid females to inbred males were used as control matings. Offspring of such crosses differ in their cytoplasmic inheritance only. The inheritance of sex-linked genes for the six pairs of reciprocal backcrosses of the present study is shown in table 1 .

\footnotetext{
Received Mar. 17, '72. Accepted Nov. 10, '72.

: Supported by NIH grant 5 T01 GM00071. The contents of this paper form a part of the author's dissertation submitted as a partial requirement for the Ph.D. degree at the University of Michigan under the direction of Professor Morris Foster.

2 Present address: Research Associate, Department of Animal Science, Animal Genetics Laboratory, University of Illinois, Urbana, Illinois 61801 .
} 
TABLE 1

Predicted sensitivities of reciprocal backcrosses of inbred females to hybrid males, and of hybrid females to inbred males, including the sex-chromosome constitutions of all offspring. The somatic genotypes of offspring of reciprocal backcrosses are identical and are not included.

\begin{tabular}{|c|c|c|c|}
\hline \multirow{2}{*}{$\underset{\left(q \times d^{\prime}\right)}{\text { Mating }}$} & \multicolumn{2}{|c|}{$\begin{array}{c}\text { X-chromosomes of } \\
\text { embryos }\end{array}$} & \multirow{2}{*}{$\begin{array}{l}\text { Predicted sensitivities } \\
\text { of reciprocal pairs }\end{array}$} \\
\hline & 99 & $0^{\circ} 0^{\circ}$ & \\
\hline $\begin{array}{l}\text { A.AB } \\
\text { A.BA }\end{array}$ & $\begin{array}{l}\mathrm{X}^{\mathrm{A}} \mathrm{X}^{\mathrm{A}} \\
\mathrm{X}^{\mathrm{B}} \mathrm{X}^{\mathrm{A}}\end{array}$ & $\begin{array}{l}X^{A} Y \\
X^{A} Y\end{array}$ & $\mathrm{~A} \cdot \mathrm{AB}>\mathrm{A} \cdot \mathrm{BA}$ \\
\hline $\begin{array}{l}\text { A.AC } \\
\text { A.CA }\end{array}$ & $\begin{array}{l}\mathbf{X}^{A} X^{A} \\
\mathbf{X}^{A} X^{C}\end{array}$ & $\begin{array}{l}X^{A} Y \\
X^{A} Y\end{array}$ & $A \cdot C A>A \cdot A C$ \\
\hline $\begin{array}{l}\text { C.BC } \\
\text { C.CB }\end{array}$ & $\begin{array}{l}\mathrm{X}^{\mathrm{B}} \mathrm{X}^{\mathrm{C}} \\
\mathrm{X}^{\mathrm{c}} \mathrm{X}^{\mathrm{c}}\end{array}$ & $\begin{array}{l}X^{\mathrm{c} Y} \\
\mathrm{X}^{\mathrm{c} Y}\end{array}$ & C.CB $>$ C.BC \\
\hline $\begin{array}{l}\text { AB.A } \\
\text { BA.A }\end{array}$ & $\begin{array}{l}\mathbf{X}^{A} \mathbf{X}^{A}, X^{A} X^{B} \\
\mathbf{X}^{A} X^{A}, X^{A} X^{B}\end{array}$ & $\begin{array}{l}X^{A} Y, X^{B} Y \\
X^{A} Y, X^{B} Y\end{array}$ & $\mathbf{A B} \cdot \mathbf{A}=\mathbf{B A} \cdot \mathbf{A}$ \\
\hline $\begin{array}{l}\text { AC.A } \\
\text { CA.A }\end{array}$ & $\begin{array}{l}\mathbf{X}^{A} \mathbf{X}^{\mathrm{A}}, \mathbf{X}^{\mathrm{A}} \mathbf{X}^{\mathrm{C}} \\
\mathbf{X}^{\mathrm{A}} \mathbf{X}^{\mathrm{A}}, \mathbf{X}^{\mathrm{A}} \mathbf{X}^{\mathrm{C}}\end{array}$ & $\begin{array}{l}X^{A} Y, X^{C} Y \\
X^{A} Y, X^{C Y}\end{array}$ & $A C \cdot A=C A . A$ \\
\hline $\begin{array}{l}\text { BC.C } \\
\text { CB.C }\end{array}$ & $\begin{array}{l}X^{\mathrm{B}} \mathbf{X}^{\mathrm{C}}, \mathrm{X}^{\mathrm{C}} \mathbf{X}^{\mathrm{c}} \\
\mathbf{X}^{\mathrm{B}} \mathbf{X}^{\mathrm{c}}, \mathbf{X}^{\mathrm{C}} \mathbf{X}^{\mathrm{C}}\end{array}$ & $\begin{array}{l}X^{B} Y, X^{C} Y \\
X^{B} Y, X^{C} Y\end{array}$ & $\mathrm{BC} . \mathrm{C}=\mathrm{CB} . \mathrm{C}$ \\
\hline
\end{tabular}

In assessing embryonic sensitivity to cortisone five indicators of sensitivity were considered: (1) CP frequency in female offspring $(\mathrm{CP} q / \mathrm{V} q)$; (2) overall $\mathrm{CP}$ frequency $(\mathrm{CP} / \mathrm{V})$; (3) proportion of males $(\delta / V)$; (4) proportion of resorptions per litter $R /(V+R)$; and (5) level of "fetal damage" per litter $[(\mathrm{CP}+\mathrm{R}) /(\mathrm{V}+\mathrm{R})]$.

These five indicators were used to test the null hypotheses that: (1) sex-linked genes do not affect embryonic sensitivity to cortisone-induced $\mathrm{CP}$ since $\mathrm{CP}+\mathrm{V} q$ and $\mathrm{CP} / \mathrm{V}$ do not differ between reciprocal crosses of inbred females to hybrid males; (2) sex-linked genes do not affect the cortisone-induced resorption rate, since $\delta / V$ and $R /(V+R)$ do not differ between reciprocal crosses; and ( 3 ) overall embryonic sensitivity to cortisone is not affected by sex-linked genes, since the incidence of $(\mathrm{CP}+\mathrm{R}) /(\mathrm{V}+\mathrm{R})$ does not differ between reciprocal crosses of inbred females to hybrid males. Matings of reciprocal hybrid females to inbred males provide the tests for parallel null hypotheses on the effects of cytoplasmic inheritance (Kalter, '54).

Discordance in the significance of differences between reciprocal crosses when indicators testing sensitivity to $\mathrm{CP}$ and to resorption are used would suggest that sensitivity to the teratogenic and the embryocidal effects of cortisone are inherited sep- arately insofar as sex-linked genes are concerned.

\section{MATERIALS AND METHODS}

Inbred $\mathrm{A} / \mathrm{J}, \mathrm{C} 57 \mathrm{BL} / 6 \mathrm{~J}$, and $\mathrm{C} 3 \mathrm{H} / \mathrm{HeJ}$ mice were obtained from the Jackson Laboratory, Bar Harbor, Maine. Reciprocal crosses between these lines produced the hybrids used in this study. Backcrosses were made to the more sensitive of the parental lines only.

Inbred mice are denoted as follows: $\mathrm{A} / \mathrm{J}$ by $\mathrm{A}, \mathrm{C} 57 \mathrm{BL} / 6 \mathrm{~J}$ by $\mathrm{B}$, and $\mathrm{C} 3 \mathrm{H} / \mathrm{HeJ}$ by $\mathrm{C}$; hybrid mice by the two letters of the parental strains, with the maternal line preceding the paternal line. Thus, $A B$ represents the offspring of a mating between an $A$ female and a $\mathrm{B}$ male; offspring of the reciprocal mating are designated by $\mathrm{BA}$. Backcrosses of $A B$ to $A$ are denoted by $A$. AB if the hybrid parent is male, and by $\mathrm{AB} . \mathrm{A}$ if the hybrid parent is female.

For experimental matings two females were placed with each male and examined daily for the presence of copulation plugs; the day on which plugs were found was considered day 0 of pregnancy. Females were treated on days $11,12,13$, and 14 of pregnancy and killed on day 17 or 18 . Treatment consisted of $1.25 \mathrm{mg}$ cortisone in saline suspension $(0.05 \mathrm{ml}$ of Cortone acetate, Merck) injected im daily. Injected 
controls received $0.05 \mathrm{ml}$ of physiological saline per day. Untreated controls were obtained for each mating. All animals were fed Purina Breeder Chow and water ad lib. Inbred females weighed 18-22 g; hybrid females 20-28 g.

For each experimental litter the number of living (V) and resorbed (R) offspring was recorded. Included in "V" were all offspring that could be classified as normal (N) or having cleft lip-cleft palate (CLP) or CP, and whose sex could be determined by gonadal examination (Beck, ' 57 ; Weir et al., '58). All visible implantations that could not be so classified were considered "resorbed." Females whose uterine horns did not contain at least one implantation were excluded from the sample.

CLPs (table 2) were excluded from the analyses since there were too few to warrant separate analysis. Saline-injected and untreated controls were pooled to form a single control group, since preliminary analysis failed to show any difference between them.

The number of litters examined per cross varied (table 2 ). Litter size varied within and between crosses, both in treated and control matings. In addition, the frequency of normal, $C P$, and resorbed offspring per litter did not approximate the normal distribution. Mann-Whitney U-sta-

\section{TABLE 2}

The total number of normal (N), cleft lip-cleft palate (CLP) and cleft palate (CP) fetuses of each sex, and the total number of resorptions $(R)$ are shown for each control and treated bachcross, together with the number of litters examined. The mean resorption rate $[R /(V+R)]$ and the sex ratio $(\sigma / V)$ are shown for control and treated crosses; the frequency of $C P$ in females (CP $\% / V q)$, of cleft palate $(C P / V)$, and of fetal damage $[(C P+R) /(V+R)]$ in treated matings are also shown.

\begin{tabular}{|c|c|c|c|c|c|c|c|c|c|c|c|c|c|}
\hline Cross & $\begin{array}{l}\text { No. of } \\
\text { litters }\end{array}$ & $\mathbf{N} \sigma^{\circ}$ & CLP 8 & $\mathrm{CP} d$ & No & CLP $q$ & $\mathrm{CP} q$ & $\mathbf{R}$ & $\frac{\mathrm{CP} q}{\mathrm{Vq}}$ & $\frac{C P}{v}$ & $\frac{\sigma}{v}$ & $\frac{\mathbf{R}}{(\mathbf{V}+\mathbf{R})}$ & $\frac{(\mathrm{CP}+\mathrm{R})}{(\mathrm{V}+\mathrm{R})}$ \\
\hline \multicolumn{14}{|c|}{ Treated } \\
\hline $\begin{array}{l}\text { A.AB } \\
\text { A.BA }\end{array}$ & $\begin{array}{l}17 \\
13\end{array}$ & $\begin{array}{r}8 \\
10\end{array}$ & $\begin{array}{l}3 \\
0\end{array}$ & $\begin{array}{l}69 \\
39\end{array}$ & $\begin{array}{r}6 \\
15\end{array}$ & $\begin{array}{l}0 \\
0\end{array}$ & $\begin{array}{l}51 \\
37\end{array}$ & $\begin{array}{l}28 \\
27\end{array}$ & $\begin{array}{l}.8947 \\
.7115\end{array}$ & $\begin{array}{l}.8955 \\
.7525\end{array}$ & $\begin{array}{l}.5839 \\
.4851\end{array}$ & $\begin{array}{l}.1697 \\
.2109\end{array}$ & $\begin{array}{l}.8970 \\
.8047\end{array}$ \\
\hline $\begin{array}{l}\text { A.AC } \\
\text { A.CA }\end{array}$ & $\begin{array}{l}12 \\
15\end{array}$ & $\begin{array}{l}6 \\
7\end{array}$ & $\begin{array}{l}1 \\
3\end{array}$ & $\begin{array}{l}46 \\
47\end{array}$ & $\begin{array}{l}14 \\
10\end{array}$ & $\begin{array}{l}2 \\
2\end{array}$ & $\begin{array}{l}25 \\
45\end{array}$ & $\begin{array}{l}32 \\
31\end{array}$ & $\begin{array}{l}.6098 \\
.7895\end{array}$ & $\begin{array}{l}.7802 \\
.8440\end{array}$ & $\begin{array}{l}.5638 \\
.5000\end{array}$ & $\begin{array}{l}.2540 \\
.2138\end{array}$ & $\begin{array}{l}.8175 \\
.8483\end{array}$ \\
\hline $\begin{array}{l}\text { C.BC } \\
\text { C.CB }\end{array}$ & $\begin{array}{l}15 \\
16\end{array}$ & $\begin{array}{l}23 \\
20\end{array}$ & $\begin{array}{l}0 \\
1\end{array}$ & $\begin{array}{l}22 \\
20\end{array}$ & $\begin{array}{l}28 \\
23\end{array}$ & $\begin{array}{l}0 \\
0\end{array}$ & $\begin{array}{l}14 \\
24\end{array}$ & $\begin{array}{l}23 \\
40\end{array}$ & $\begin{array}{l}.3333 \\
.5106\end{array}$ & $\begin{array}{l}.4138 \\
.5057\end{array}$ & $\begin{array}{l}.5172 \\
.4659\end{array}$ & $\begin{array}{l}.2091 \\
.3125\end{array}$ & $\begin{array}{l}.5364 \\
.6563\end{array}$ \\
\hline $\begin{array}{l}\text { AB.A } \\
\text { BA.A }\end{array}$ & $\begin{array}{l}16 \\
17\end{array}$ & $\begin{array}{l}40 \\
39\end{array}$ & $\begin{array}{l}2 \\
0\end{array}$ & $\begin{array}{l}39 \\
45\end{array}$ & $\begin{array}{l}41 \\
41\end{array}$ & $\begin{array}{l}1 \\
0\end{array}$ & $\begin{array}{l}35 \\
31\end{array}$ & $\begin{array}{l}12 \\
14\end{array}$ & $\begin{array}{l}.4545 \\
.4305\end{array}$ & $\begin{array}{l}.4684 \\
.4872\end{array}$ & $\begin{array}{l}.5127 \\
.5385\end{array}$ & $\begin{array}{l}.0706 \\
.0706\end{array}$ & $\begin{array}{l}.5059 \\
.5294\end{array}$ \\
\hline $\begin{array}{l}\text { AC.A } \\
\text { CA.A }\end{array}$ & $\begin{array}{l}18 \\
14\end{array}$ & $\begin{array}{l}8 \\
5\end{array}$ & $\begin{array}{l}0 \\
4\end{array}$ & $\begin{array}{l}65 \\
45\end{array}$ & $\begin{array}{l}10 \\
10\end{array}$ & $\begin{array}{l}7 \\
1\end{array}$ & $\begin{array}{l}56 \\
42\end{array}$ & $\begin{array}{l}24 \\
43\end{array}$ & $\begin{array}{l}.7671 \\
.7925\end{array}$ & $\begin{array}{l}.8705 \\
.8529\end{array}$ & $\begin{array}{l}.5000 \\
.5047\end{array}$ & $\begin{array}{l}.1412 \\
.2867\end{array}$ & $\begin{array}{l}.8529 \\
.8667\end{array}$ \\
\hline $\begin{array}{l}\text { BC.C } \\
\text { CB.C }\end{array}$ & $\begin{array}{l}26 \\
16\end{array}$ & $\begin{array}{l}76 \\
49\end{array}$ & $\begin{array}{l}0 \\
0\end{array}$ & $\begin{array}{l}30 \\
17\end{array}$ & $\begin{array}{l}80 \\
41\end{array}$ & $\begin{array}{l}0 \\
0\end{array}$ & $\begin{array}{l}29 \\
21\end{array}$ & $\begin{array}{l}31 \\
18\end{array}$ & $\begin{array}{l}.2661 \\
.3387\end{array}$ & $\begin{array}{l}.2744 \\
.2969\end{array}$ & $\begin{array}{l}.4930 \\
.5156\end{array}$ & $\begin{array}{l}.1260 \\
.1233\end{array}$ & $\begin{array}{l}.3659 \\
.3836\end{array}$ \\
\hline \multicolumn{14}{|c|}{ Controls } \\
\hline $\begin{array}{l}\text { A.AB } \\
\text { A.BA }\end{array}$ & $\begin{array}{r}11 \\
9\end{array}$ & $\begin{array}{l}43 \\
45\end{array}$ & $\begin{array}{l}1 \\
1\end{array}$ & $\begin{array}{l}0 \\
0\end{array}$ & $\begin{array}{l}49 \\
33\end{array}$ & $\begin{array}{l}1 \\
0\end{array}$ & $\begin{array}{l}0 \\
0\end{array}$ & $\begin{array}{l}10 \\
15\end{array}$ & $\overline{-}$ & - & $\begin{array}{l}.4681 \\
.5823\end{array}$ & $\begin{array}{l}.0962 \\
.1596\end{array}$ & $\overline{-}$ \\
\hline $\begin{array}{l}\text { A.AC } \\
\text { A.CA }\end{array}$ & $\begin{array}{l}9 \\
9\end{array}$ & $\begin{array}{l}41 \\
35\end{array}$ & $\begin{array}{l}3 \\
2\end{array}$ & $\begin{array}{l}0 \\
0\end{array}$ & $\begin{array}{l}44 \\
47\end{array}$ & $\begin{array}{l}1 \\
0\end{array}$ & $\begin{array}{l}0 \\
0\end{array}$ & $\begin{array}{r}12 \\
2\end{array}$ & - & - & $\begin{array}{l}.4944 \\
.4405\end{array}$ & $\begin{array}{l}.1188 \\
.0233\end{array}$ & - \\
\hline $\begin{array}{l}\text { C.BC } \\
\text { C.CB }\end{array}$ & $\begin{array}{l}12 \\
12\end{array}$ & $\begin{array}{l}36 \\
45\end{array}$ & $\begin{array}{l}0 \\
1\end{array}$ & $\begin{array}{l}0 \\
0\end{array}$ & $\begin{array}{l}40 \\
46\end{array}$ & $\begin{array}{l}0 \\
0\end{array}$ & $\begin{array}{l}0 \\
0\end{array}$ & $\begin{array}{l}8 \\
9\end{array}$ & - & - & $\begin{array}{l}.4737 \\
.5000\end{array}$ & $\begin{array}{l}.0952 \\
.0891\end{array}$ & - \\
\hline $\begin{array}{l}\text { AB.A } \\
\text { BA.A }\end{array}$ & $\begin{array}{l}15 \\
11\end{array}$ & $\begin{array}{l}73 \\
52\end{array}$ & $\begin{array}{l}0 \\
0\end{array}$ & $\begin{array}{l}0 \\
0\end{array}$ & $\begin{array}{l}77 \\
44\end{array}$ & $\begin{array}{l}0 \\
0\end{array}$ & $\begin{array}{l}0 \\
0\end{array}$ & $\begin{array}{l}7 \\
4\end{array}$ & $\overline{-}$ & - & $\begin{array}{l}.4867 \\
.5417\end{array}$ & $\begin{array}{l}.0446 \\
.0400\end{array}$ & - \\
\hline $\begin{array}{l}\text { AC.A } \\
\text { CA.A }\end{array}$ & $\begin{array}{r}14 \\
7\end{array}$ & $\begin{array}{l}64 \\
36\end{array}$ & $\begin{array}{l}0 \\
1\end{array}$ & $\begin{array}{l}0 \\
0\end{array}$ & $\begin{array}{l}57 \\
34\end{array}$ & $\begin{array}{l}1 \\
2\end{array}$ & $\begin{array}{l}0 \\
0\end{array}$ & $\begin{array}{l}8 \\
7\end{array}$ & - & - & $\begin{array}{l}.5246 \\
.5068\end{array}$ & $\begin{array}{l}.0616 \\
.0875\end{array}$ & - \\
\hline $\begin{array}{l}\text { BC.C } \\
\text { CB.C }\end{array}$ & $\begin{array}{l}10 \\
13\end{array}$ & $\begin{array}{l}46 \\
49\end{array}$ & $\begin{array}{l}0 \\
0\end{array}$ & $\begin{array}{l}0 \\
0\end{array}$ & $\begin{array}{l}47 \\
66\end{array}$ & $\begin{array}{l}0 \\
0\end{array}$ & $\begin{array}{l}0 \\
0\end{array}$ & $\begin{array}{r}4 \\
10\end{array}$ & - & - & $\begin{array}{l}.4946 \\
.4261\end{array}$ & $\begin{array}{l}.0430 \\
.0800\end{array}$ & - \\
\hline
\end{tabular}


tistics (Waerden, '69) were used to assign an approximate probability to the data for each indicator and each reciprocal-cross pair (e.g., A.AB/A.BA) under the null hypothesis: the offspring of a reciprocal-cross pair do not differ with respect to the indicator. A combined probability test (Fisher, '36; Sokal and Rohlf, '69) was then used to test the overall null hypothesis for each type of mating (i.e., of inbred females to hybrid males and of hybrid females to inbred males).

\section{RESULTS AND DISCUSSION}

Table 2 lists the number of treated and control litters examined for each cross; the total number of normal, CLP, and CP young of each sex per cross; and the number of resorptions for each cross. In addition the proportion of males $(\delta / V)$ and of resorptions $[R /(V+R)]$ are shown for control and treated crosses, and the $\mathrm{CP}$ frequency in females ( $C P q / V q)$, in all young $(\mathrm{CP} / \mathrm{V})$, and the frequency of CP plus resorption $[(C P+R) /(V+R)]$ are shown for treated crosses.

It must be stressed that these summaries do not form the basis of the statistical tests, since both the U-test and the combined probability test are nonparametric (distribution-free), and so assume no relations between means, standard errors, and ranges of the distributions they test. Nevertheless, the means remain the simplest single statement of data sets, and so are presented here, together with the number of litters on which they are based.

Table 3 presents the results of the statistical analyses. The use of three strains and five fetal indicators allowed the hypotheses to be evaluated on several levels. Each hypothesis was tested with respect to each pair of strains independently of the other two pairs of strains (U-test), and the results of these three independent evaluations were used to estimate the combined probability of the observed data under the null hypothesis holding in each reciprocal-cross pair. Fisher's combined probability test applies because U-statistics furnish an estimate for the probability, under the null hypothesis, for the data to be ordered in the observed manner.

Among control matings only the reciprocal crosses A.AC and A.CA differed significantly. The incidence of resorptions, as measured by $R /(V+R)$, was higher among offspring of $A C$ sires than of $\mathrm{CA}$ sires $(P=.04)$. Since the model predicts that A.CA litters should show greater sensitivity to cortisone, the control results indicate that the differences found between A.AC and A.CA in treated matings should be enhanced by this factor. The combined probabilities that in controls reciprocal crosses of inbred females to hybrid males differed with respect to $R /(V+R),(C P+R) /(V+R)$, or $\delta / V$ were not statistically significant.

For treated matings of hybrid females to inbred males the greatest differences be-

TABLE 3

U-test probabilities under the null hypothesis, and results of the combined probabilities test: probabilities for treated matings of inbred females to hybrid males are one-sided; for control matings and for matings of reciprocal hybrid females to inbred males two-sided probabilities are shown

\begin{tabular}{|c|c|c|c|c|c|c|c|}
\hline \multirow{2}{*}{ Cross } & \multicolumn{5}{|c|}{ Treated } & \multicolumn{2}{|c|}{ Control } \\
\hline & $\mathrm{CP} q / \mathrm{V} q$ & $\mathrm{CP} / \mathrm{V}$ & $\sigma / v$ & $\mathbf{R} /(\mathbf{V}+\mathbf{R})$ & $(\mathbf{C P}+\mathbf{R}) /(\mathbf{V}+\mathbf{R})$ & $0 / \mathrm{V}$ & $\mathbf{R} /(\mathbf{V}+\mathbf{R})$ \\
\hline $\begin{array}{l}\text { A.AB /A.BA } \\
\text { A.AC/A.CA } \\
\text { C.BC/C.CB }\end{array}$ & $\begin{array}{l}.093 \\
.090 \\
.029\end{array}$ & $\begin{array}{l}.142 \\
.176 \\
.065\end{array}$ & $\begin{array}{l}.132 \\
.102^{1} \\
.251^{1}\end{array}$ & $\begin{array}{l}.069^{1} \\
.394^{1} \\
.251^{1}\end{array}$ & $\begin{array}{l}.054 \\
.452 \\
.050\end{array}$ & $\begin{array}{l}.142 \\
.436 \\
.999\end{array}$ & $\begin{array}{l}.496 \\
.040 \\
.522\end{array}$ \\
\hline $\begin{array}{l}\text { Combined } \\
\text { probability }\end{array}$ & $P<.02$ & $P<.05$ & $p<.10$ & N.S. ${ }^{2}$ & $P<.05$ & N.S. & N.S. \\
\hline $\begin{array}{l}\text { AB.A/BA.A } \\
\text { AC.A/CA.A } \\
\text { BC.C/CB.C }\end{array}$ & $\begin{array}{l}.322 \\
.378 \\
.596\end{array}$ & $\begin{array}{l}.522 \\
.718 \\
.542\end{array}$ & $\begin{array}{l}.264 \\
.822 \\
.992\end{array}$ & $\begin{array}{l}.396 \\
.108 \\
.970\end{array}$ & $\begin{array}{l}.764 \\
.596 \\
.774\end{array}$ & $\begin{array}{l}.204 \\
.448 \\
.222\end{array}$ & $\begin{array}{l}.696 \\
.834 \\
.170\end{array}$ \\
\hline $\begin{array}{l}\text { Combined } \\
\text { probability }\end{array}$ & N.S. & N.S. & N.S. & N.S. & N.S. & N.S. & N.S. \\
\hline
\end{tabular}

1 Direction of difference reversed from predicted.

2 Not statistically significant. 
tween reciprocal crosses were between the offspring of AC.A and CA.A with respect to $R /(V+R)$, but were not significant $(P=.11)$. As shown in table 3 none of the combined probabilities for indicators of embryonic sensitivity permit rejection of the null hypothesis that offspring of reciprocal crosses between hybrid females and inbred males derive from the same population.

The a priori model of sex-linked inheritance of sensitivity to cortisone was originally drawn from data on cortisone-induced CP (Fraser et al., '54; Kalter, '54, '65; Loevy, '63). The model was extended to include embryonic sensitivity to cortisoneinduced resorption when data were obtained showing that inbred lines differed in their response to the embryocidal effects of cortisone (Francis, '71).

Of the five fetal indicators whose distributions were studied two measure embryonic sensitivity to cortisone-induced $\mathrm{CP}-\mathrm{CP}+\mathrm{V} q$ and $\mathrm{CP} / \mathrm{V}$. The distribution of $\mathrm{CP}$ in female offspring of reciprocal hybrid males is the primary indicator for the influence of sex-linked genes on cortisoneinduced $\mathrm{CP}$. For the reciprocal cross pairs A.AB /A.BA and A.AC/A.CA the probability that offspring of reciprocal males derive from the same population is about .09 . For the reciprocal cross pair C.BC/C.CB the probability is about .03 . The relative embryonic sensitivities in each pair of crosses corresponded to the direction predicted by the model; i.e., offspring of $\mathrm{AB}$, $\mathrm{CA}$, and $\mathrm{CB}$ sires were more sensitive to cortisone-induced $\mathrm{CP}$ than offspring of $\mathrm{BA}$, $\mathrm{AC}$, and $\mathrm{BC}$ sires, respectively. The combined probability of the observed data if the null hypothesis holds in each case is less than .02.

The indicator $\mathrm{CP} / \mathrm{V}$ does not distinguish the sex of offspring. Since male offspring of reciprocal backcrosses never differ in their X-chromosome constitution the inclusion of male offspring blunts the precision of the indicator. If the maternal abilities of the inbred dams are limited the increased resistance of female embryos might be compensated for by increased morbidity among male sibs of resistant-Xchromosome females. Even in the absence of such a contingency $\mathrm{CP} / \mathrm{V}$ adds the considerable between-litter variation in sex ratios to the other within-cross variations (litter size, number of viable embryos). Therefore CP/V is not as good an indicator of sex-linked effects on cortisone-induced $\mathrm{CP}$ as $\mathrm{CP}$ \% V $\mathrm{V}$.

Of the three reciprocal-cross pairs of inbred females to reciprocal hybrid males C.BC/C.CB may have differed in the proportion of $\mathrm{CP} / \mathrm{V}$ in their offspring ( $P=$ $.07)$. The relative embryonic sensitivities in each pair of crosses corresponded to the directions predicted by the model (table 1 ). The combined probability of the observed data if the null hypothesis holds in each case is less than .05 and statistically significant.

The data were therefore consistent with the hypothesis that the $\mathrm{A}, \mathrm{B}$, and $\mathrm{C}$ strains differ with respect to sex-linked genes affecting embryonic sensitivity to cortisoneinduced $C P$. The direction of observed differences is in accord with the a priori model.

Two indicators measured embryonic sensitivity to the embryocidal effects of cortisone $-\sigma / V$ and $R /(V+R)$. If cortisone results in sex-biased resorptions, proportionally more surviving offspring should be male in those crosses with sensitive-Xchromosome females; i.e., the proportion of males should be depressed in those litters sired by $\mathrm{BA}, \mathrm{AC}$, and $\mathrm{BC}$ males, respectively. This was clearly not found to be the case. The differences between reciprocal crosses were not statistically significant (table 3 ); moreover the directions were reversed from the predicted in two cases. AC and BC males produced a larger proportion of male offspring than their reciprocals, $\mathrm{CA}$ and $\mathrm{CB}$. The combined probability, like the individual probabilities, is not statistically significant at the .05 level.

The resorption rate, as measured in this study, includes only postimplantation losses recognizable on day 17 or 18 of pregnancy. Earlier studies showing that resorption rate in the presence of cortisone was independent of strain (Fraser et al., '54) measured whole-litter resorptions, including preimplantation loss, but excluding litters with one or more liveborn young (Fraser and Fainstat, '51). Postimplantation loss, as measured here by $R /(V+R)$, depends on several genetic variables including strain (Francis, '71). 
The resorption rate in reciprocal crosses of inbred females to hybrid males did not differ significantly. In two reciprocal cross pairs, A.AB/A.BA and A.AC/A.CA, the relative resorption rates were reversed from the directions predicted by the model. The combined probability of the observed data if the null hypothesis holds in each case is greater than .05. The data do not, therefore, support the hypothesis that sexlinked genes affecting embryonic sensitivity to cortisone-induced resorption differ between the $\mathrm{A}, \mathrm{B}$, and $\mathrm{C}$ strains.

The level of fetal damage, $(\mathrm{CP}+\mathrm{R}) /$ $(\mathrm{V}+\mathrm{R})$, measures the overall sensitivity of a mating to cortisone, and includes both the teratogenic and the embryocidal effects of cortisone. For each reciprocal-cross pair the relative embryonic sensitivities were as predicted: the level of fetal damage corresponds, qualitatively, to the theory. The greatest difference was found between C.BC and C.CB $(P=.05)$; the difference between A.AB and A.BA $(P=.05)$ approached significance. The combined probability test permitted rejection $(P<.05)$ of the null hypothesis that offspring of reciprocal crosses derive from the same population with respect to $(C P+R) /(V+R)$.

The precision of $(C P+R) /(V+R)$ is blunted if sensitivity to the embryocidal effects of cortisone is not inherited in the same manner as sensitivity to the teratogenic effects. On the assumption that $\mathrm{CP}$ and resorption are discontinuous observations on an underlying continuum of response to cortisone one would expect similar results for the indicators $\mathrm{CP} / \mathrm{V}$ and $R /(V+R)$, and indeed for all indicators of cortisone sensitivity. When, as in the present case, dissimilar results are found the usefulness of the overall indicator of sensitivity is reduced.

Ordinarily the backcross design used in the present study could also be used to test for the influence of uterine effects on embryonic sensitivity to cortisone. The critical comparison for uterine effects is between the offspring of inbred and hybrid dams (Bornstein et al., '70). The somatic genotypes of offspring of, e.g., A.AB, A.BA, $A B . A$, and BA.A are identical. The expected sex-chromosome constitution of offspring of hybrid dams is not, however, the same as the expected sex-chromosome constitutions of offspring of inbred dams (table 1). Accordingly, any comparisons for uterine effects would, in the present study, be confounded with the sex-linked effects.

Although the emphasis throughout the discussion has been on the effects of sexlinked genes it must be stressed that it is not claimed that sex-linked genes account for all of the reciprocal effects found in these inbred lines. Considerable evidence exists that this is not the case (Kalter, ' 54 ; Loevy, '63; Francis, '71).

The evidence presented is, however, consistent with the hypothesis that sexlinked genes affect embryonic sensitivity to cortisone-induced $\mathrm{CP}$ in the $\mathrm{A}, \mathrm{B}$, and C strains. The data do not support the hypothesis that sex-linked genes affect embryonic sensitivity to cortisone-induced resorption in these three strains. By extrapolation, it is suggested that inheritance of sensitivity to the teratogenic and embryocidal effects of cortisone may in part be mediated by separate genes.

\section{ACKNOWLEDGMENT}

The author is indebted to Professor $R$. Bohrer of the Mathematics Department, the University of Illinois at UrbanaChampaign, for suggesting the statistical methods used to analyze the data.

\section{LITERATURE CITED}

Beck, S. L. 1957 Prenatal sex ratio and mortality in three lines of mice. M. A. Thesis, University of Kansas, Lawrence.

Bornstein, S., D. G. Trasler and F. C. Fraser 1970 Effect of the uterine environment on the frequency of spontaneous cleft lip in CL/Fr mice. Teratology, 3: 295-298.

Fisher, R. A. 1936 Statistical Methods for Research Workers. Sixth ed. Oliver and Boyd, London.

Francis, B. M. 1971 Inheritance of sensitivity to the teratogenic and embryocidal effects of cortisone in four strains of mice. Ph.D. Thesis, University of Michigan, University Microfilms, Ann Arbor, Michigan 48104.

Fraser, F. C, and T. D. Fainstat 1951 Production of congenital defects in offspring of pregnant mice treated with cortisone. Pediatrics, 8 : 527-533.

Fraser, F. C., H. Kalter, B. E. Walker and T. D. Fainstat 1954 Experimental production of cleft palate with cortisone and other hormones. J. Cell. Comp. Physiol., 43, Suppl. 1: 237-259. 
Kalter, H. 1954 The inheritance of susceptibility to the teratogenic action of cortisone in mice. Genetics, 39: 185-196.

1965 Interplay of intrinsic and extrinsic factors. In: Teratology: Principles and Techniques. J. B. Wilson and J. Warkany, eds. Univ. of Chicago Press, Chicago, pp. 57-80.

Loevy, H. 1962 Developmental changes in the palate of normal and cortisone treated Strong $a$ mice. Anat. Rec., 142; 375-390.
1963 Genetic influences on induced cleft palate in different strains of mice. Anat. Rec., 145: 117-122.

Sokal, R. R., and F. J. Rohlf 1969 Biometry. Freeman, San Francisco.

Waerden, B. L. van der 1969 Mathematical Statistics. Springer, New York.

Weir, J. A., H. Haubenstock and S. L. Beck 1958 Absence of differential mortality of sexes in mice. J. Hered., 49: 217-222. 